\title{
Coastal Community Welfare of Mining Areain Kotabaru Regency, South Kalimantan Province
}

\author{
Ahmad Alim Bachri ${ }^{1}$, Udiansyah $^{1}$, Nasruddin $^{2}$ and Deasy Arisanty ${ }^{2}$ \\ 1. Faculty of Economic, Lambung Mangkurat University, Banjarmasin 70123, Indonesia \\ 2. Faculty of Teaching and Education Science, Lambung Mangkurat University, Banjarmasin 70123, Indonesia
}

\begin{abstract}
Kotabaru is richregency in mining and plantations. The sector has contributed to the regional income in the regency. Coastal communities in the area can certainly get the impact which is marked by the increasing prosperity of society. This study used a survey by sampling using questionnaire. The number of samples in this study were 100 respondents who live in the Serakaman village and the Ujung village of Sebuku sub-district, Kotabaru. Companies in the Serakaman village and the Ujung village are Sebuku Iron Lateritic Ores (SILO), Bahari Cakrawala Sebuku (BCS) and Metalindo Bumi Raya (MBR). Analysis stages of welfare based on the level of welfare standards from National Population and Family Planning Board of Indonesia. The results showed the level of welfare in the Sarakaman village and the Ujung village is the welfare stage I and the welfare stage. Although at this welfare stage I and welfare families, the level of education, access to banks and income is still low. The company through its Corporate Social Responsibility (CSR) program is expected to improve the welfare of the community around the company area.
\end{abstract}

Key words: Welfare, coastal, community, mining.

\section{Introduction}

Abundant resources and strategies for resource uses is a determinant of economic growth. The meaning is the physical factor and a factor in the management of resource utilization determining economic growth [1]. The resources are abundant marine and coastal region of Indonesia. The resource has the potential to build a strong economy for Indonesia [2]. Increased public economy should be accompanied by increased prosperity in coastal areas.

Poverty is a state with a lower ability to meet basic needs such as food, shelter, health and safety [3]. Causes of poverty in coastal areas is the limited of public revenues, lower public welfare, low investment, limited employment opportunities and high unemployment [4].

Number of poverty in Indonesia based on National Population and Family Planning Board of Indonesia data decreases every year. Poverty people of Indonesia

Corresponding author: Deasy Arisanty, Ph.D., research field: geography. in 2012 are about 29,132 or $11.96 \%$. Poverty people in year 2013 are about 28,066 or $11.37 \%$. Percentage of poverty people in south Kalimantan are about $4.77 \%$.

The level of welfare in Indonesia based on National Population and Family Planning Board of Indonesia classification are grouped into three stages, namely pre-welfare stages, welfare family stage I and welfare family. Pre-welfare families are families who do not meet their basic needs. Welfare family stages $I$ is a family that has been able to meet their basic needs but can not meet the needs of social psychology. Welfare family is a family that has been able to meet basic needs, psychological and social development of the family, but have not been able to contribute to society.

The level of welfare of coastal communities in mining areas should increase along with the use of land around their homes. The reality is that there are still many coastal areas on the poverty line despite the abundant natural resources [5].

Kotabaru district is a district located in the eastern part of south Kalimantan province. This district is 
known for its abundance of both marine natural resources and mining resources. The layout of this district was strategically located between two large islands of Kalimantan and Sulawesi. Its strategic geographic location makes this district become economically strategic [6-8].

Mining in Kotabaru district are coal and iron ore which are scattered throughout the district of Kotabaru $[6,7]$. The existence of this company should be able to have a positive impact on the economy of the community which in turn can improve the well-being of coastal communities around the mining area and the plantation.

\section{Research Methods}

The method used in this study is a survey method. Survey region are coastal areas in the mining area in Kotabaru district which is in district Sebuku. Some companies in the district Sebuku is Sebuku Iron Lateritic Ores (SILO), Bahari Cakrawala Sebuku (BCS) and Metalindo Bumi Raya (MBR). The village located around the area of this company is Serakaman village and the Ujung village $[6,7]$. The number of Sebuku residentis 7,650 inhabitants [9]. Samples are coastal communities in the Serakaman village and Ujung village which lives $>500 \mathrm{~m}$ and $<500 \mathrm{~m}$ from the location of the company. The total number of samples were 100 respondents, with 50 respondents in the Serakaman village and 50 respondents in the Ujungvillage. Serakaman village directly adjacent to the BCS and MBR companies while Ujung village directly adjacent to SILO company. The analysis is based on the criteria of National Population and Family Planning Board of Indonesia. The variables and indicators used are:

The basis for determining the level of prosperous families is based on variable stages of a prosperous family. If there are criteria that do not meet one variable at this stage of welfare family, then being classified into a welfare family stage I. If there is a variable that does not meet the welfare stage $\mathrm{I}$, then being classified into pre-welfare stages.

Table 1 Stages of family welfare.

\begin{tabular}{|c|c|}
\hline Indicator & Sub Indicator \\
\hline Pre-welfare stages & The family did not met one of the indicators for clothing, food, shelter, healthand education. \\
\hline \multirow{5}{*}{ Welfare family stages 1} & To worship according to the religious affiliation of each; \\
\hline & Eat two times a day or more; \\
\hline & Clothes for different purposes; \\
\hline & The house floor is not made of soil; \\
\hline & the sick child is brought to the facility/health workers. \\
\hline \multirow{16}{*}{ Welfare family stages } & Family members regularly practice their religion according to the religious affiliation of each; \\
\hline & At least once a week the family was providing meat/fish/eggs as a side dish; \\
\hline & Obtain a new outfit in the last year; \\
\hline & The floor area per occupant of the house is $8 \mathrm{~m}^{2}$; \\
\hline & Members of a family in a healthy state in the last three months, so that it can perform the function of each; \\
\hline & Families who are 15 years old or older have regular income; \\
\hline & Can read and write for family members of adults aged $10-60$ years; \\
\hline & All children aged $7-15$ years in school at this time; \\
\hline & Two or more children live and today still use contraceptives; \\
\hline & Families have efforts to increase religious knowledge; \\
\hline & The family have money savings; \\
\hline & Families usually eat together at least once a day; \\
\hline & Participate in community activities; \\
\hline & Families hold recreation at least once in 6 months; \\
\hline & Families can get news from newspapers/radio/television/magazine; \\
\hline & Family members can use the transportation facility. \\
\hline
\end{tabular}




\section{Results and Discussion}

\subsection{Characteristics of the Region}

Sebuku sub-district is geographically located at 03'24'32.2” $\mathrm{S}$ and 116 24'25.7" E. Sebuku sub-district has an area of $245.50 \mathrm{~km}^{2}$. The population of the sebuku island district is 6,960 inhabitants. Populous contained in Sekapung village with a population of 1,506 inhabitants and an average of 41 inhabitants $/ \mathrm{km}^{2}$. The population of the Serakaman village is 819 inhabitants. The largest area of village is located in the Kanibungan village with an area of 46 $\mathrm{km}^{2}$. Serakaman village have an area of $34 \mathrm{~km}^{2}$, and the Ujung village have an area of $36.5 \mathrm{~km}^{2}$ [10]. Banjar Tribe is the dominant tribe settled in the Serakaman village and the Ujung village. The Banjar tribe has settled about 30 years in the Serakaman village and the Ujung village. In addition to Banjar tribe, other tribe that in this region is Bugis. Banjar and Bugis tribes coexist peacefully and mating occurs among the different tribes. Intermarriage has led to acculturation, for example, on the language used in everyday life, the term substitute name and the marriage ceremony [10].

BCS has been operating in the District Sebuku in 1997. The mining system is an open system. Mining area carried out by BCS in 2007 was 9,004 ha with an area of 5,871 ha being assisted by two contractors: MBR (2,885 ha) and KM (248 ha), with the permission of exploitation 3 million tons/year [10, 11]. SILO began operations in Sebuku Island in 2004 after BCS [11]. BCS and SILO expands exploitation area to the Serakaman village in 2010 [11]. BCR has had a village built as a form of responsibility to the surrounding community. The village built of BCR is Serakaman village, Mandin village, Belambus village, Sekapung village and Kanibungan village [10].

\subsection{The Level of Public Welfare in Serakaman Village}

\subsubsection{Religion and Ethnicity}

Religious affiliation of village communities
Serakaman around BCS and MBR companies is islam. Tribe in the Serakaman village around BCS and MBR companies is a banjar tribes rate of $92 \%$ and $8 \%$ of Bugis tribes. Comunity of Serakaman village around BCS and MBR companies are devout religious believers to practice their religion regularly and improve their knowledge in religion. This means that the religious villagers in the Serakaman district Sebuku Island has been good.

\subsubsection{Education}

The education level of the Serakaman village community around BCS and MBR companies is the majority of primary school graduates. The percentage of primary school graduates is $54 \%$, junior high school graduates is $16 \%$, high school graduates is $20 \%$ and diploma/bachelor is $6 \%$. Serakaman village community around BCS and MBR companies can read and write latin despite their education majority from primary school graduates. In addition, people of school age in school due to the condition of school facilities elementary and junior high schools is already available in the region. This means that the education community Serakaman village in Sebuku Island around BCS and MBR companies has been good.

\subsubsection{Work and Income}

The job of Serakaman village community around BCS and MBR companies is the majority of employees. Percentage of employees in companies are $44 \%$, fisherman is $18 \%$, self-employed is $16 \%$, farmers is $14 \%$, and civil servants is $8 \%$. Percentage of community income $>1,500,000$ is $94 \%$. Percentage of income $<1,500,000$ is $6 \%$. People have a regular income with diverse types of work and have a sufficient income to meet their daily needs. Citizens are able to provide side dishes for food. Citizens are also able to buy clothes. Low earnings causing some people can not afford to spend money on recreation. Approximately $6 \%$ of low-income people are not being able to recreation.

3.2.4 Residential Home

The home stay of serakaman village community 


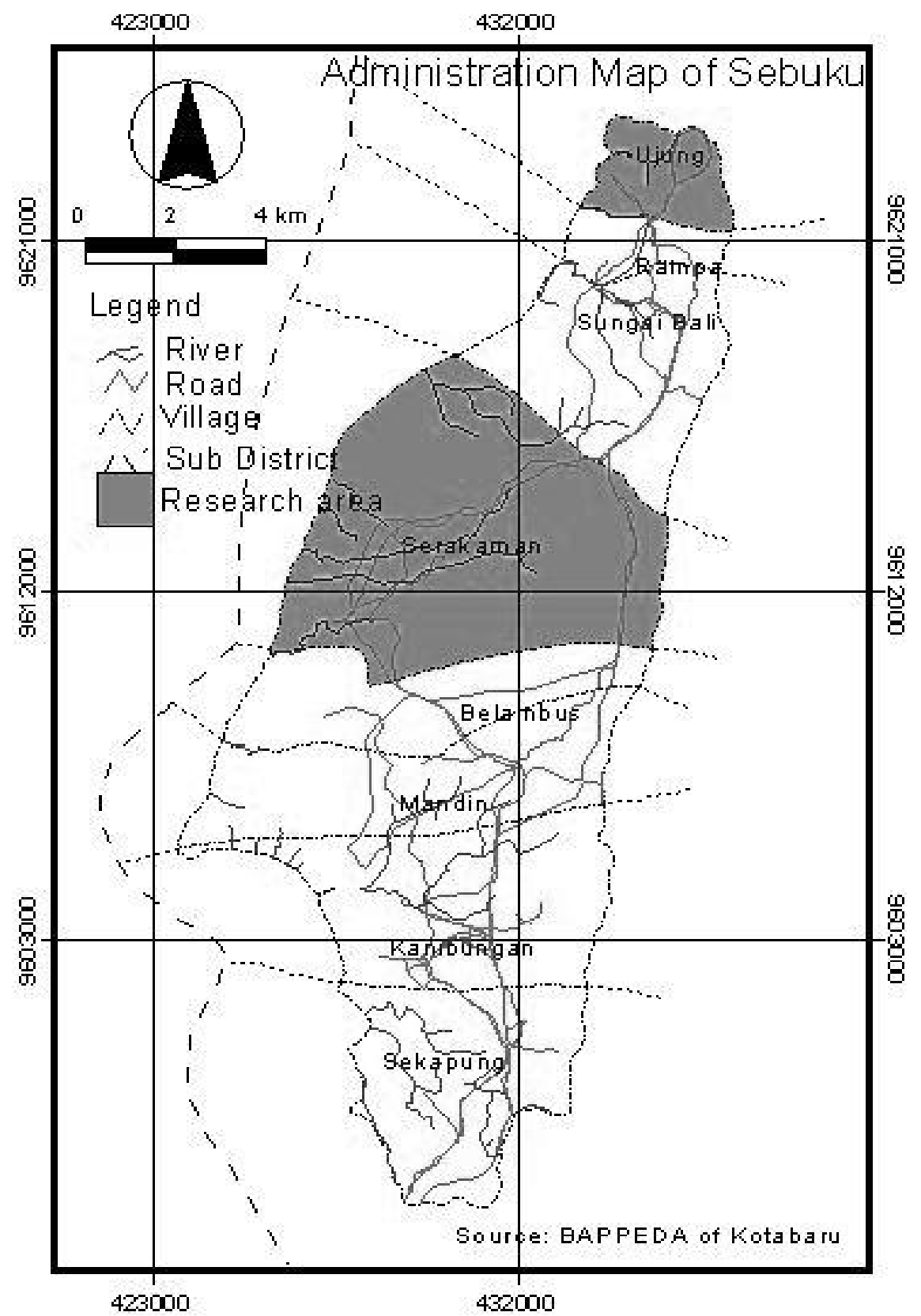

Fig. 1 Administration map of Sebuku Island.

around BCS and MBR companies are majority-owned whose percentages is $88 \%$. While broad of their homes are more than $8 \mathrm{~m}^{2}$. This means that the residence in Serakaman village around BCS and MBR companies is already quite good.

\subsubsection{Health}

Public health of Serakaman village around BCS and MBR companies are in good condition, as access to health services readily available. Clinics distance from their place is $30-400$ meters. Serakaman village community around BCS and MBR companies in the last three months is in a healthy state because of getting the health services, so they can carry out their respective functions. The community also have used contraceptives and implemented immunization. This means that the health of the Serakaman villagers 


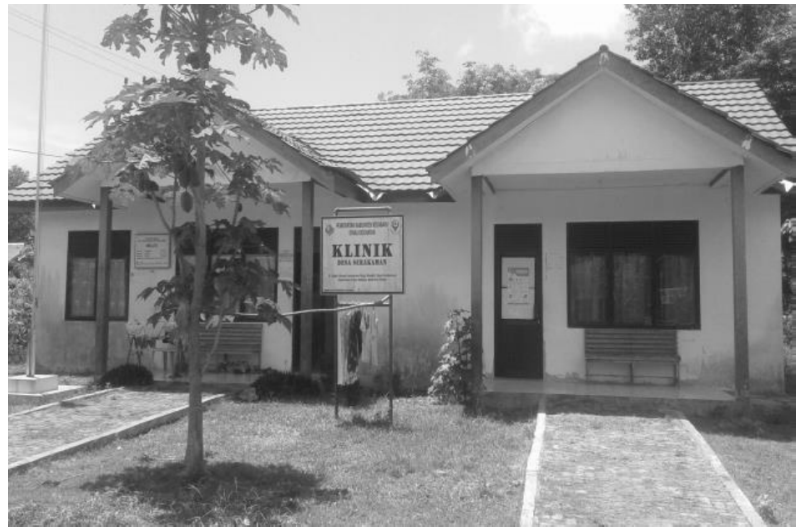

Fig. 2 Clinic in Serakaman village.

around BCS dan MBR companies is good. The condition of health facilities in the Serakaman contained in Fig. 2.

\subsubsection{Savings}

Majority of Serakaman village community around BCS dan MBR companies have no savings of money in bank, but they have the savings in the form of gold. There are limited access to bank and cultural societies prefer to save in the form of gold deposits compared to the savings bank.

\subsubsection{Social Capital}

Majority of Serakaman village community around BCS dan MBR companies has participation of mutual cooperation and security of the region although it is not scheduled. The Serakaman village communities are always leaving an open attitude towards migrants.

\subsubsection{Information}

Information obtained by the public through television, radio and newspapers. Information from the television is easily obtained by the public because they are readily available access to electricity in the Serakaman village. $100 \%$ of the citizens already have access to electricity. Therefore, people in the Serakaman village already have a good in gaining access to information.

\subsubsection{Transportation}

The road access in Serakaman village around BCS dan MBR companies is in good condition. The type of road is hardening. Facility of transportation is a private motorcycle. This means that the public transport in Serakaman village around BCS dan MBR companies is already good.

Category of Serakaman villagers welfare around BCS dan MBR companies are welfare families stages I and welfare family. A total of $94 \%$ of the public entrance on the stage of welfare families and $6 \%$ entered the welfare stage I due to about $6 \%$ of the people cannot recreation and have the low income. Although most people already belong to the group of welfare families, but need to improve on some aspects, among others:

(1) Education, still high that society less educated;

(2) Access to bank, bank facilities also need to be in the region to improve public access to the bank;

(3) Income, public revenue is quite high because more than 1,500,000.00 rupiah, but the income is still relatively low when compared with the high cost of living in the district Sebuku [11].

Assistance by the company in the form of Corporate Social Responsibility (CSR) program is in the form of roads, educational facilities, markets, scholarships, places of worship and health facilities. Community knowledge of the CSR programs is still relatively low, only about $8 \%$ were aware of CSR programs, $20 \%$ less knowing, and $72 \%$ of people do not know [10]. Meaning is not all people get the information and assistance regarding CSR program. The CSR program is not optimally improve the welfare of the people in the Serakaman village.

\subsection{Community Welfare in Ujung Village}

\subsubsection{Religious and Ethnic}

Religious affiliation of Ujung village communities around the SILO company is Islam. While the tribe in the Ujung village around SILO company consist of $56 \%$ of Banjar ethnic, $42 \%$ of Bugis ethnic and $2 \%$ of Madura ethnic. Ujung village community around SILOcompany is devout religious believers to practice their religion regularly. This means that the religious in Ujung village community is already good. 


\subsubsection{Education}

The education level of the Ujung village community around SILO company is elementary and middle school graduates. Percentages of education level in Ujung villages are $36 \%$ of elementary and junior high graduates, $20 \%$ of high school graduates, and $8 \%$ of diploma/undergraduate. Family members of adults aged 10-60 years have the ability of reading and writting. In addition, people of school age in school due to the condition of school facilities elementary and junior high schools is already available in the region. This means that the education of Ujung village comunity around SILO company is already good because it is able to read and write although many are less educated. Educational facilities in the ujung village are contained in Fig. 3.

\subsubsection{Work and Income}

Jobs of Ujung village comunity around SILO company are a majority of private sector employees. The percentage of private sector jobs is $40 \%$, farmers and traders is $28 \%$, and self-employed is $18 \%$. Ujung village community around SILO family aged 15 years and above has a regular income. Most people are employees of the company. Community income per month is $1,000,000-2,000,000$ rupiah by $72 \%$ and $28 \%$ income of 2,000,000-3,000,000 rupiah per month. The income that the community is only able to meet the needs of food and clothing, but most people are not able to recreation.

\subsubsection{Residential Home}

The home stay of Ujung village around SILO company is a majority-owned himself with the usual types of wooden houses. Spacious of house they live more than $8 \mathrm{~m}^{2}$ with a toilet inside their homes. This means that the community residences of Ujung village district Sebuku Island around SILO company are in good categories.

\subsubsection{Health}

Healtines of Ujung village around SILO company is a majority in good condition. Ujung village comunity in the last three months is in a healthy condition.

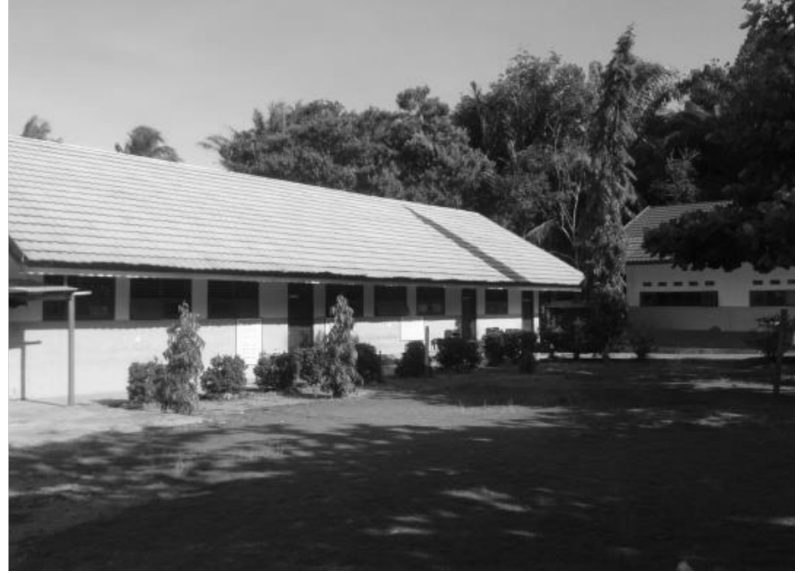

Fig. 3 Elementary school in Ujung village.

Health community center access is easy and affordable cost to the health center. Community led to the ease to obtain healthcare, treatment, obtain family planning services and get immunization. This means that the public health of ujung village included is in good categories.

\subsubsection{Savings}

Ujung village communities in Sebuku Island around SILO company do not save money in the bank, there were only $5 \%$ who have savings in the bank, but they have savings in the form of gold. This is because access to bank distant and cultural societies prefer to save in the form of gold deposits compared to the savings in bank. That is the Ujung village district of Sebuku Island around SILO company included in good categories.

\subsubsection{Social Capital}

Ujung village communityin Sebuku Island around SILO company participates in activities of mutual cooperation although is not scheduled and always participated in regional security. Ujung village community kinship in Sebuku Island is strong. This means that the social capital of Ujung village included is in good categories.

\subsubsection{Information}

Information is obtained through print media and electronic media. The print media information obtained through newspapers and books, while the electronic media through television and radio. The 
easiest information obtained through the television. People's access to television broadcasts is very easy for this village which also has access to electricity. Therefore, the Ujung village community to get the information included in good categories.

\subsubsection{Transportation}

The road access in Ujung village around SILO company within easy condition to be passed with the type of asphalt road. Ujung village community has the own private motorcycle for transportation. This means that the public transport in Ujung village included is in good categories.

Based on several indicators from the National Population and Family Planning Board of Indonesia, welfare of the Ujung village community around SILO community are family welfare stages I and welfare family which means it can meet its basic needs. A total of $72 \%$ of the society include the category of welfare stage I and $28 \%$ include the category stages of welfare family. Society has a job and an income. They have a stable job, and have their own homes despite the usual kind of wooden houses. The indicators also strengthened in terms of savings, although the majority of people do not have savings in the bank, but they have savings in the form of gold deposits.

The same conditions with Sarakaman villageand the Ujung village also have problems in education. The villages are also low bank access and low income. Although the community is classified in welfare families stages I and welfare family, but their living standards are still very low. A total of $36 \%$ of the society is still less educated, $80 \%$ of people have little access to banks, and $72 \%$ of people have income $<$ $1,500,000$ rupiah [7]. An improvement in the economic life of the community is to improve the welfare of society through CSR programs of the company. The most important point of the CSR program is to increase society's ability to survive and help people out of poverty [12]. Forms of CSR activities that have a positive correlation with the welfare of society are the goal of corporate social responsibility, corporate social issues and corporate relations program [13]. The fact that occurred in the Ujung village is $60 \%$ of the people are not informed about the program in the company $[10,14]$. Therefore, CSR program information needs to be disseminated by the company so that the company's presence could affect the economic life of society.

\section{Conclusion}

The welfare level of Serakaman village around BCS and MBR companies and Ujung village communities around SILO company based on indicators from National Population and Family Planning Board of Indonesia are welfare families stages I and welfare family. Although in terms of public education is still low, the majority only finished elementary school, they have jobs and incomes. Community has the house with the usual types of wooden houses. The majority of people do not have savings in the bank because the access is difficult, but they have savings in the form of gold deposits. Access to information also can be obtained by either, as well as transportation access.

\section{References}

[1] Riana, I. G., Wiagustini, N. L. P., and Meydianawathi, L. G. 2015. "The Efforts for Coastal Community Welfare Improvement and Economic Developent Acceleration in Bali Province." Journal of the International Association of Advanced Technology and Science 16: 1.

[2] Tajerin. 2009. "Political Economic Role of Coastal and Marine Resources Management in Promoting Sustainable Development." Mangrove and Coastal Journal 9 (1) 18-28.

[3] Bradshaw, T. K. 2006. "Theories of Poverty and Anti-Poverty Programs in Community Development." In Rural Poverty Research Centre (RPRC) Working Paper, 5-6.

[4] O'Connor, K. 2004. "Understanding and Managing Coastal Economic Development." Presented at National Coastal Symposium.

[5] Sundah Daisy, I. E., Suman Soemano, A., and Kindangen, P. 2013. "How Coastal Development, Environmental Change, and Adaptive Behavior Affects Fishermen's Welfare? (A Study of Traditional Fishermen from the 
Coastal Area of Manado Bay, Indonesia).” IOSR Journal of Humanities and Social Science 17 (4): 24-34.

[6] Bachri, A. A., and Udiansyah, N., and Arisanty, D. 2014. "Economic Characteristic of Coastal Community at Mining Region, Kotabaru Regency, Indonesia." Journal of Environmental Science and Engineering A 3: 1-13.

[7] Bachri, A. A., Udiansyah, N., and Arisanty, D. 2014. Management Model of Economic Empowerment in Coastal Area of Mining, Kotabaru Regency, Indonesia. Research report.

[8] Bachri, A. A., Udiansyah, N., and Arisanty, D. 2016. Coastal Community Empowerment in Mining Area of Kotabaru. Banjarmasin, Indonesia: LMU Press.

[9] Central Berau of Statistic (BPS). 2013. "Number of Kotabaru People Based on Gender." Accessed February 20, 2015. http://kotabarukab.bps.go.id/linkTableDinamis/ view/id/816.
[10] Bachri, A. A., Nasruddin Mattiro, S., Setiadi, D., and Ziyad, M., 2013. Social Mapping of Bahari Cakrawala Sebuku Guidance Villages. Research report.

[11] Hakim, L., Kinseng, R. A., and Agusta, I. 2015. "Mining and Structural Poverty of Small Island Community (Case Study of Rural Community in Sarakaman, Sebuku Island, Kotabaru, South Kalimantan)." Journal of Rural Sociology 3 (1): 24-36.

[12] Ismail, M. 2009. "Corporate Social Responsibility and Its Role in Community Development: An International Perspective." The Journal of International Social Research 2 (9): 199-209.

[13] Mapisangka, A. 2009. "Implementation of CSR Program for Community Welfare.” JESP 1: 1.

[14] Bachri, A. A., and Nasruddin Mattiro, S. 2014. Study of Community Attitudes and Perceptions about Corporate Social Responsibility (CSR) Program in Kotabaru Regency. Research report. 